\title{
Comparison of three chemical tests to assess seed viability: the seed dispersal system of the Macaronesian endemic plant Rubia fruticosa (Rubiaceae) as an example
}

\author{
Patricia Marrero $^{1}$, David P. Padilla ${ }^{1}$, Francisco Valdés ${ }^{2}$ and Manuel Nogales ${ }^{1}$ \\ ${ }^{1}$ Island Ecology and Evolution Research Group (IPNA, CSIC), C/ Astrofísico Francisco Sánchez nº 3, 38206 La Laguna, Tenerife, Canary Islands, Spain \\ ${ }^{2}$ Applied Plant Biology Group, Plant Biology Department, University of La Laguna, 38206 La Laguna, Tenerife, Canary Islands, Spain.
}

\begin{abstract}
Summary. Three chemical viability tests were evaluated in the seed dispersal system of Rubia fruticosa, in which three main groups of dispersers participate: reptiles, birds and mammals. Tetrazolium chloride (TTC) and indigo carmine (IC) indicated a lower viability of seeds from droppings of introduced rabbits (Oryctolagus cuniculus) than of those from control plants and the native dispersers, lizards and gulls. In the rabbit seed treatment, significant differences were observed between results obtained with TTC and IC tests. Interpretation of these data, due to the presence of doubtful embryo staining, was more difficult using the IC test. Furthermore, some seeds that were clearly dead had been underestimated. In contrast with results obtained from the two staining methods, the EC test did not confirm that viability of control seeds and those seeds consumed by native dispersers were clearly higher than in seeds ingested by $O$. cuniculus. Further, compared to the other two tests, the EC method requires more careful handling of the embryo during the extraction process to avoid errors in viability estimation, since this method measures concentration of electrolytes that are released through cellular membranes. Thus, TTC was the most reliable test to assess seed viability in the seed dispersal system of $R$. fruticosa, and these results agree with those obtained in previous germination experiments made on the same set of seeds given the same treatments.
\end{abstract}

Key words. Tetrazolium - Indigo carmine Electroconductivity - Macaronesian Islands - Rubia fruticosa - Vertebrate dispersers

\section{Introduction}

In seed dispersal systems, animals (mainly terrestrial vertebrates) play an important role in determining the success of this critical stage in the life cycles of plants (Murray, 1986; Fleming and Estrada, 1993; Fenner, 2000; Stiles, 2000; Levey et al. 2001). Thus, one of the most influential factors in these systems is the mechanical and chemical effects that

Correspondence to: Manuel Nogales, e-mail: mnogales@ipna.csic.es dispersers have on the seed coat (Stevens, 1988; Robbins, 1993; Schupp, 1993). The effects on seeds passed through the digestive tracts of dispersers can be evaluated using seed germination and chemical viability tests. The simultaneous study of these procedures is especially useful in cases where germination percentage is low, in which case it cannot be determined if the seeds are non-viable or dormant (see Baskin and Baskin, 2001; Hidayati et al., 2002). Furthermore, it is important to note that germination may be inhibited for several reasons, including anaerobic atmospheres, extremes temperatures, dry conditions, different acid types, among others (Murdoch and Ellis, 1992). Further, in seed dispersal systems in which germination of seeds of control plants is relatively high (e.g. > 80\%), the use of chemical viability tests is also useful, because seeds consumed by different types of vertebrates can cause a decrease in germination percentage (Traveset, 1998; CalviñoCancela, 2004; Rodríguez-Pérez et al., 2005).

Three classes of vertebrates are involved in most seed dispersal systems in terrestrial environments: reptiles, birds and mammals (Stiles 2000). However, they often do not participate simultaneously (Nogales et al., 2005), primarily due to two factors: 1) saurochory (dispersal by lizards) is mainly an island phenomenon (Olesen and Valido, 2003), and 2) some seed disperser mammals such as large bats and carnivores often are not present on islands. However, in the Canary Islands these three groups may coexist in the same habitats and share the same fruit-plant resource (Nogales et $a l ., 2005)$. This is the case in Rubia fruticosa (Rubiaceae), an endemic plant of the Macaronesian archipelagos of Madeira, Salvages and Canaries in which reptiles, birds and mammals participate in the seed dispersal system, simultaneously (Nogales et al., 2005). In this system, seed germination percentage clearly decreased after passed through the gut of two introduced mammal species (rabbits and desert squirrels) with respect to control seed plants and those eaten by native dispersers (lizards and birds). Therefore, in these cases only the use of chemical techniques to examine viability permits us to understand if seeds consumed by different vertebrates are dead or dormant. However, relatively few studies have assessed both seed germination and seed viability simultaneously (see Traveset, 1998). 
Certain biochemical tests can be used to assess seed viability (Dias et al., 1998; Nam et al., 1998). However, the experimental conditions should be previously optimized to avoid lack of uniformity in the results that might be difficult to interpret (Tanaka, 1984; Nam et al., 1998; Chang et al., 1999). Until now, most chemical seed viability tests in seed dispersal systems have used the tetrazolium method (Traveset, 1998), and we do not know of any study in which different chemical methods of seed viability have been compared. Thus, the purpose of our study was to compare the efficiency of the tetrazolium method with two other commonly chemical techniques used for assessing seed viability in studies on seed dispersal, namely the indigo carmine and electroconductivity tests.

\section{Material and methods}

\section{Seed dispersal system of Rubia fruticosa}

Rubia fruticosa is a shrub that grows in the Canarian Archipelago lowlands and can reach a mean cover of $\approx 0.49 \mathrm{~m}^{2}$ and a mean height of $0.54 \mathrm{~m}(n=100$ plants $)$ in the eastern Canary Islands (Lanzarote and Fuerteventura) (Nogales et al., 2005). Its fleshy fruits are spherical translucent berries with a mean length of 7.5 $\mathrm{mm}$, a diameter of $5.6 \mathrm{~mm}$, a fresh mass of $0.2 \mathrm{~g}$, a dry mass of $037 \mathrm{~g}$, and a water content of $81.5 \%$. Mean number seeds/fruit is 1.4 , and mean seed mass $8.2 \mathrm{mg}(n=40$ fruits, Nogales et al., 1999). Seeds of control plants of this species have a relatively high germination percentage, and thus a low level of dormancy (Nogales et al., 2001). Since the R. fruticosa seed dispersal system has been studied in depth, we compared three chemical methods commonly applied to test seed viability.

Seeds

The three chemical viability tests were evaluated using seeds of $R$. fruticosa in the Malpaís de La Corona (northern Lanzarote, Canary Islands). Rubia fruticosa seeds were collected from droppings $(n=42)$ of Gallotia atlantica (a small endemic lizard to the eastern Canary Islands), droppings $(n=80)$ of Oryctolagus cuniculus (an introduced mammal to all islands of the archipelago) and pellets $(n=5)$ of Larus cachinnans (a gull mainly distributed in coastal areas). Two control samples also were taken: living seeds from mature fruits (positive control) and seeds killed by boiling them for 3-5 min (negative control). Fifty seeds per treatment were used. After soaking seeds in distilled water for 24 hours, embryos were extracted carefully under a stereomicroscope $(10 \times$ magnifications) to assess results of the chemical viability tests. The same set of seeds of the different treatments (control, Gallotia, Larus and Oryctolagus) was used in each viability test.

\section{Chemical viability tests}

Embryo viability was estimated by three methods:

(1) In the tetrazolium chloride test (TTC), viable embryos stained red due to reduction of 2,3,5-triphenyltetrazolium chloride by respiratory activity in the cells (Nachlas et al., 1960). Individual embryos were incubated in TTC solutions diluted to $1 \%$ and $0.1 \%$ in phosphate buffer ( $\mathrm{pH} 7$ ) for 24 hours in the dark at room temperature (Scharpf, 1970; Tanaka, 1984).

(2) In the indigo carmine test (IC), individual embryos were completely immersed for three hours in solutions of indigo carmine diluted to $0.2 \%$ and to $0.1 \%$. In this technique, nonviable embryos turn blue due to increased membrane permeability in dead cells, whereas viable ones remain white (Kamra, 1972).

(3) In the electroconductivity test (EC), 50 embryos per treatment were immersed in $30 \mathrm{ml}$ Milli-Q water for 24 hours. Electroconductivity values in the water extracts were measured in microsiemens/g using a conductimeter (Crison 524, Crison Instruments). Decrease in viability is manifested by increase in electroconductivity as a result of electrolyte release through cellular membranes in dead cells (Moreno et al., 2001).

To ensure correct interpretation of the colour patterns of embryos in the chemical TTC and IC tests, and to define the limiting values for the EC test, seed control samples (living and dead) were analysed first. Solutions of TTC diluted to $0.1 \%$ and of those IC diluted to $0.2 \%$ gave the best results. Embryos were considered to be viable when $90-100 \%$ of their surface stained red by TTC test (Bhering et al., 2005; Oliveira et al., 2005) and non-viable when they turned dark blue in the IC test (Kamra, 1972). In the EC test, viable embryos should have values smaller than those of the negative control sample (dead embryos).

\section{Statistical analysis}

A total of 50 seeds were used in each TTC and IC test. These methods permit the counting of both living and dead individual seeds based on their staining pattern. However, in the EC method it is essential to use a group of seeds that permits the measurement of the concentration of electrolytes that is lower in small seeds, such as in the case of $R$. fruticosa than in large seeds. For this reason, electroconductivity was measured at the same time for all 50 embryos. However, to compare results of the three viability methods, it was necessary to transform the values of EC (microsiemens/g). Taking into account that all seeds from the negative control were killed by boiling, and that we know the total amount of electrolytes in all 50 seeds, we can calculate the quantity of electrolytes released by one dead seed using a single extrapolation. So, we can infer the number of dead seeds in each treatment of EC. Likelihood Ratio Tests were used to assess differences between TTC, IC and EC methods, by considering the absolute number of dead or living seeds per treatment (SPSS version 12.0).

\section{Results and discussion}

Results of the TTC and IC tests indicated that viability was lower in seeds from $O$. cuniculus droppings than in those from native dispersers (Table 1). These results agree with those for germination reported by Nogales et al. (2005) for $R$. fruticosa, in which the same set of seeds per treatment was used. These authors concluded that native birds and reptiles dispersed a high proportion of undamaged seeds, while introduced mammals (O. cuniculus) caused significant seed damage. However, the difficulty in interpreting our data varied depending on the chemical viability test used, particularly for seeds extracted from rabbit droppings. Embryo viability was estimated clearly by the TTC test, but the percentage of doubtful embryos, especially from $O$. cuniculus droppings, was significantly higher for the IC solution $(42 \%)\left(\mathrm{G}_{1}=24.11 ; \mathrm{p}<0.001\right)$. Twenty percent of these doubtful embryos were slightly stained, which did not provide a clear conclusion regarding their viability, while $22 \%$ of the remainder were partially or totally fragmented and unstained. Therefore, this latter group, which was clearly non-viable, was underestimated by the IC test.

In contrast to results obtained from the TTC and IC methods, the EC test did not confirm that viability of control seeds and those consumed by native dispersers was clearly higher than in those seeds ingested by $O$. cuniculus (Table 1) Furthermore, this method requires great caution to avoid injuring the embryos during extraction. In this respect, mean diameter of $R$. fruticosa seeds $2.33 \pm 0.22 \mathrm{~mm}$, thus a small 
amount of damage to the embryo could have caused errors in viability estimation by the EC test. This method measures the concentration of electrolytes that are released through cellular membranes, which is higher when cells are damaged. Thus, the EC test may be more sensitive to possible damage to embryos during extraction. Viable seeds of control plants and those consumed by Gallotia and Larus constituted practically $100 \%$ of the stock analysed by TTC and IC tests. However, a similar decrease in viable seed percentage was observed using EC test for these three treatments (Table 1), which could be considered an error due to the manipulation of embryos. On the other hand, the degree of this error could be smaller in seeds from Oryctolagus since rabbits produce clear external damage to seeds, which is observed in TTC and IC test results.

Results of this study indicate that the TTC test is the simplest and most reliable method to determine viability in the seed dispersal system of $R$. fruticosa. The TTC and the EC tests are accepted as methods of testing viability by the International Rules for Seed Testing (ISTA, 1999), although the TTC test is the most widely useful. This method has been successfully used to predict germination and seedling growth of a wide range of species (Moreno et al., 2001; Bhering et al., 2005; Oliveira et al., 2005), as well as viability of tissues of land plant (Duncan and Widholm, 2004; Siuta et al., 2005) and of diverse species of algae (Nam et al., 1998; Chang et al., 1999). However, the majority of these studies are based on plant species of agricultural and forestry interest. Thus, as far as we know, this is the first study to compare the three most common chemical methods for estimating seed viability from an ecological perspective on a particular seed dispersal system.

\section{Acknowledgements}

The authors thank Jerry Baskin for his helpful editorial comments and Carol Baskin and the Editor Désiré Daloze for their assistance. Benigno Padrón and Raquel Gutiérrez collaborated in the laboratory. This research was supported by grants to Patricia Marrero and David P. Padilla from the Proyectos Intramurales Especiales, 20043 OE 169 of the Spanish National Scientific Research Council (Consejo Superior de Investigaciones Científicas) and the Canarian Government, respectively. It was partially financed by the projects BOS2001-0610 (Ministerio de Educación y Ciencia) and PI042004/037 (Consejería de Educación, Cultura y Deportes, Gobierno de Canarias), which are partially supported by Feder funds from the European Union.

\section{References}

Baskin CC, Baskin JM (2001) Seeds: ecology, biogeography, and evolution of dormancy and germination. San Diego: Academic Press

Bhering MC, Dias DCFS, Barros DI (2005) Adequação da metodologia do teste de tetrazólio para avaliação da qualidade fisiológica de sementes de Melancia. Rev Bras sementes 27: $176-182$

Calviño-Cancela M (2004) Ingestion and dispersal: direct and indirect effects of frugivores on seed viability and germination of Corema album (Empetraceae). Acta Oecol 26: 55-64 
Chang WC, Chen MH, Lee TM (1999) 2,3,5-Triphenyltetrazolium reduction in the viability essay of Ulva fasciata (Chlorophyta) in response to salinity stress. Bot Bull Acad Sinica 40: 207-212

Dias DCFS, Vieira AN, Bhéring MC (1998) Conductividade elétrica e lixiviação de potasio para avaliação do vigor de sementes de hortalizas: feijão-de-vagem e quiabo. Rev Bras sementes 20: 170-175

Duncan DR, Widholm JM (2004) Osmotic induced stimulation of the reduction of the viability dye 2,3,5-triphenyltetrazolium chloride by maize roots and callus cultures. J Plant Physiol 161: 397-403

Fenner M (ed) (2000) Seeds: the ecology of regeneration in plant communities, 2nd edn. Wallingford: CABI Publishing

Fleming TH, Estrada A (eds) (1993) Frugivory and seed dispersal: ecological and evolutionary aspects. Dordrecht, Kluwer: Academic Publishers

Hidayati SN, Baskin JM, Baskin CC (2002) Effects of dry storage on germination and survivorship of seeds of four Lonicera species (Caprifoliaceae). Seed Sci Tech 30: 137-148 (+ erratum, vol. 31 , issue 3,2003 )

ISTA (1999) International Rules for Seed Testing: Annexes 1999. Seed Sci Technol 24: 155-202

Kamra SK (1972) Comparative studies on germinability of Pinus silvestris and Picea abies seed by the indigo carmine and $\mathrm{X}$ ray contrast methods. Stud For Suec 99: 1-21

Levey DJ, Silva WR, Galetti M (eds) (2001) Seed dispersal and frugivory: ecology, evolution and conservation. Wallingford: CABI Publishing

Moreno MT, Benito LF, Herrero N, Domínguez S, Peñuelas JL (2001) Estudio de nuevos métodos de determinación de la viabilidad de las semillas forestales: test de electroconductividad e índigo carmín. Comparación con el test del tetrazolio y su aplicación a Pinus pinaster y Pinus halepensis. Actas del III Congreso Forestal Español, Granada, Mesa 3: 653-658

Murdoch AJ, Ellis RH (1992) Longevity, viability and dormancy. Pp. 139-229 in: Fenner M (ed) Seeds: the ecology of regeneration in plant communities. Wallingford, Oxon: CAB International

Murray DR (1986) Seed dispersal. Sydney: Academic Press Nachlas MM, Margulies SI, Seligman AM (1960) Sites of electron transfer to tetrazolium salts in the succinoxidase system. J Biol Chem 235: 2739-2743

Nam BH, Jin HJ, Kim SK, Hong YK (1998) Quantitative viability of seaweed tissues assessed with 2,3,5-triphenyltetrazolium chloride. J Appl Phycol 10: 31-36

Nogales M, Hernández EC, Valdés F (1999) Seed dispersal by common ravens Corvus corax among island habitats (Canarian Archipelago). Écoscience 6: 56-61
Nogales M, Medina FM, Quilis V, González-Rodríguez M (2001) Ecological and biogeographical implications of YellowLegged Gulls (Larus cachinnans Pallas) as seed dispersers of Rubia fruticosa Ait. (Rubiaceae) in the Canary Islands. J Biogeogr 28: 1137-1145

Nogales M, Nieves C, Illera JC, Padilla DP, Traveset A (2005) Effect of native and alien vertebrate frugivores on seed viability and germination patterns of Rubia fruticosa (Rubiaceae) in the eastern Canary Islands. Funct Ecol 19: 429-436

Olesen JM, Valido A (2003) Lizards as pollinators and seed dispersers: an island phenomenon. Trends Ecol Evol 18: 177-181 Oliveira LM, De Carvalho MLM, Davide AC (2005) Teste de tetrazólio para avaliação da qualidade de sementes de Peltophorum dubium (Sprengel) Taubert - Leguminosae Caesalpinioideae. Cerne 11: 159-166

Robbins CT (1993) Wildlife feeding and nutrition. San Diego: Academic Press

Rodríguez-Pérez J, Riera N, Traveset A (2005) Effect of seed passage through birds and lizards on emergence rate of Mediterranean species: differences between natural and controlled conditions. Funct Ecol 19: 669-706

Samuels IA, Levey DJ (2005) Effects of gut passage on seed germination: do experiments answer the question they ask?. Funct Ecol 19: 365-368

Scharpf RF (1970) Seed viability, germination and radicle growth of dwarf mistletoe in California. USDA Forest Service Research Paper PSW-59

Schupp EW (1993) Quantity, quality and the effectiveness of seed dispersal by animals. Pp. 15-29 in: Fleming TH, Estrada A (eds) Frugivory and seed dispersal: ecological and evolutionary aspects. Dordrecht, Kluwer: Academic Publishers

Siuta A, Bozek M, Jedrzejczyk M, Rostañski A, Kuta E (2005) Is the Blue Zinc Violet (Viola guestphalica Nauenb.) a taxon of hybrid origin? Evidence from embryology. Acta Biol Cracov Bot 47: 237-245

Stevens CE (1988) Comparative physiology of the vertebrate digestive system. New York: Cambridge University Press

Stiles EW (2000) Animals as seed dispersers. Pp. 111-124 in: Fenner M (ed) Seeds: the ecology of regeneration in plant communities, 2nd ed. Wallingford: CABI Publishing

Tanaka Y (1984) Assuring seed quality for seedling production: cone collection and seed processing, Testing, Storage, and Stratification. Pp 27-39 in: Duryea ML, Landis TD (eds) Forest, nursery manual: production of bareroot seedlings. The Hague: Martinus Nijhoff/Dr W. Junk Publishers,

Traveset A (1998) Effect of seed passage through vertebrate frugivores' guts on germination: a review. Perspect Plant Ecol Evol Syst 1/2: 151-190 